\title{
Synthesis, Spectral Characterization and Biological Evaluation of Cr(III) Complex with Mixed N,N and O-donor Ligands
}

\author{
R Govindharaju ${ }^{1, *}$, N Muruganantham ${ }^{1}$, S Balasubramaniyan ${ }^{2}$, L Palanivelan², B Jayalakshmi ${ }^{3}$, K Rajalakshmi ${ }^{4}$, T Ramachandramoorthy ${ }^{5}$ \\ 'Postgraduate and Research Department of Chemistry, Thanthai Hans Roever College (Autonomous), (Affiliated to Bharathidasan University), Perambalur, Tamil Nadu, \\ INDIA. \\ 2Postgraduate and Research Department of Chemistry, Government Arts College (Affiliated to Bharathidasan University), Ariyalur, Tamil Nadu, INDIA. \\ ${ }^{3}$ Department of Chemistry, Syed Ammal Engineering College (Affiliated to Anna University), Ramanathapuram, Tamil Nadu, INDIA. \\ ${ }^{4}$ Postgraduate and Research Department of Chemistry, Srimad Andavan Arts and Science College (Affiliated to Bharathidasan University), Tiruchirappalli, Tamil Nadu, \\ INDIA. \\ SPostgraduate and Research Department of Chemistry, Bishop Heber College (Autonomous), (Affiliated to Bharathidasan University), Tiruchirappalli, Tamil Nadu, INDIA.
}

\begin{abstract}
Objectives: 2-aminobenzonitrile is used as the starting materials for the synthesis of many biologically active compounds. The main objective of the study was to synthesize, characterization and biological evaluation of a binuclear bridged $\mathrm{Cr}(\mathrm{III})$ complex containing 2-aminobenzonitrile (N,Ndonor) and octanoate ion (OC) as ligands. Methods: This study formulated, the required mole ratio of 2 -aminobenzonitrile in methanol and sodium octanoate in ethanol were added to the chromium chloride in methanol followed by microwave irradiation for few seconds after each addition by using microwave oven and the precipitate was filtered off, washed with 1:1 ethanol: water and characterized by various spectral studies and biological significance. Results: The resulted complex was investigated by the help of elemental analysis, molar conductance, magnetic moment, electronic spectra, FT-IR, cyclic voltammetry, thermal analysis and powder-XRD techniques. The spectral data's indicates that the geometry of the complex is octahedral. The antimicrobial activities of ligands and their $\mathrm{Cr}$ (III) complex were studied by agar-well diffusion method. The free radical scavenging
\end{abstract}

activity of the complex and the ligands has been determined by measuring their interaction with the stable free radical DPPH. DNA-binding properties have been studied by fluorescence-emission method. Conclusion: The for mulated $\mathrm{Cr}$ (III) complex showed moderate and potential activity against the tested bacteria, enhanced activity against the fungi and larger antioxidant activity as compared to the free ligands. The DNA binding study result suggests that the complex strongly binds to DNA.

Key words: 2-aminobenzonitrile, N,N-donor, Antimicrobial, DNA binding

\section{Correspondence}

Dr. R Govindharaju,

Postgraduate and Research Department of Chemistry, Thanthai Hans Roever College (Autonomous), (Affliated to Bharathidasan University), Perambalur-621220, Tamil Nadu, INDIA.

Phone no: +919444561010

Email: argovindh@gmail.com

DOI: 10.5330/ijpi.2019.4.30

\section{INTRODUCTION}

The structure of hybrid inorganic - organic coordination complexes is of high interest in crystal engineering which aims to predict and control the fashion molecules assemble in the solid state..$^{1-4}$ In the designing of coordination complexes with unique properties for a wide range of prospective applications including gas storage, ${ }^{5}$ antimicrobial, ${ }^{6}$ conductive material, ${ }^{7}$ luminescent, ${ }^{8}$ and magnetic materials. ${ }^{9}$ Among the aminobenzonitriles, 2 -aminobenzonitrile $(\mathrm{ABN})$ is used for the induction of nitrilase activity in arthrobacter, radio protective agent and starting materials for the synthesis of biologically active compounds. ${ }^{10,11} 2$-aminobenzonitrile is one of the organic ligand in coordination chemistry which can coordinate to the metal ion through different modes viz., monodentate, bidentate or bridging. In general, the biological activities of the metal complexes differ from those of either the ligand or the metal ion itself and increased and/or decreased biological activities are reported for various metal complexes. ${ }^{12}$ On the other hand, synthesis of inorganic/organic compounds using microwave irradiation has been a very rapidly developing technique in research area. ${ }^{13,14}$ Compared with the conventional method, microwave technique is promising due to its unique effects, such as rapid volumetric heating, higher reaction rates, higher reaction selectivity, higher yields of products and energy saving.

The present study aims at synthesis and spectral characterization of Cr(III) complex with neutral bidentate 2-aminobenzonitrile and anionic

monodentate octanoate ion as ligands. The biological activities of the ligands and their complex have also been focused in this study.

\section{MATERIALS AND METHODS}

\section{Materials}

2-aminobenzonitrile, sodium octanoate and chromium nitrate were purchased from Alfa Aaser Company and used as such. The organic solvents DMSO, DMF, methanol, ethanol were of AnalaR grade and used as such without further purification.

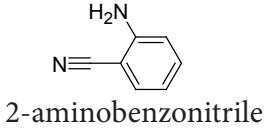

\section{Methods}

\section{Synthesis of $\mathrm{Cr}$ (III) complex}

2-aminobenzonitrile $0.45 \mathrm{~g}(3.79 \mathrm{mmol})$ in $10 \mathrm{ml}$ methanol and sodium octanoate $1.25 \mathrm{~g}(7.53 \mathrm{mmol})$ in $10 \mathrm{ml}$ ethanol were added to the chromium chloride $1.00 \mathrm{~g}(2.50 \mathrm{mmol})$ in $10 \mathrm{ml}$ methanol followed by $\mathrm{mi}-$ crowave irradiation for a few seconds after each addition by using IFB 25 BG-1S model microwave oven. The consequential precipitate was filtered 
off, washed with 1:1 ethanol: water mixture and desiccated under vacuum. A green colored complex was obtained with $85.76 \%$ yield.

\section{Instrumentations}

CHN elemental analyses were performed using Thermo Finnegan make, Flash EA1112 Series CHNS(O) analyzer. The molar conductivity measurement was conducted using $10^{-3} \mathrm{M}$ solutions of the metal complex in acetonitrile with Systronic Conductivity Bridge (model number-304) at $30^{\circ} \mathrm{C}$. The electronic spectrum of the $\mathrm{Cr}$ (III) complex was recorded on Varian, Cary 5000 model UV Spectrophotometer. Infra-red spectra for the complexes and the ligands were recorded on a Perkin Elmer, Spectrum RX-I, FT-IR spectrometer in $\mathrm{KBr}$ discs at room temperature. The cyclic voltammogram of the complex was taken in acetonitrile medium using Princeton make (MC-Tech, Applied Research) equipment. Tetraethylammoniumbromide was used as the supporting electrolyte. The thermogravimetric analysis of the complex was carried out using Perkin Elmer Diamond TGA/DTA Instrument. The powder X-ray diffraction analysis of the complex was recorded on a Rigaku model X-ray Diffractometer.

\section{Biological activities}

\section{Antimicrobial activity}

The free ligands and their Cr(III) complex were tested for in-vitro antimicrobial activity by the well diffusion method using agar nutrient as the medium. The antibacterial and the antifungal activities of the ligands and the $\mathrm{Cr}$ (III) complex was evaluated by well diffusion method against the strains, cultured on potato dextrose agar as medium. The stock solution $\left(10^{-2} \mathrm{M}\right)$ was prepared by dissolving the compounds in DMSO and the solutions were successively diluted at different concentration $(\mu \mathrm{g} /$ $\mathrm{ml})$. According to the typical procedure a well was made on the agar medium inoculated with the micro-organisms. The well was filled with the test solution using a micropipette and the plate was incubated for $24 \mathrm{hr}$ for bacteria and $72 \mathrm{hr}$ for fungi at $35^{\circ} \mathrm{C}$. At the end of the period, inhibition zones formed on the medium were evaluated in millimeters $(\mathrm{mm})$ and diameter. ${ }^{15}$

\section{Antioxidant activity}

Evaluation of antioxidant activity stock solution $(1 \mathrm{mg} / \mathrm{ml})$ was diluted to final concentrations of $10-500 \mu \mathrm{g} / \mathrm{ml}$. Ethanolic DPPH solution $(1 \mathrm{ml}$, $0.3 \mathrm{mmol}$ ) was added to the sample solutions in DMSO $(3 \mathrm{ml})$ at different concentrations $(10-500 \mu \mathrm{g} / \mathrm{ml}) .{ }^{16}$ The mixture was shaken energetically and acceptable to stand at room temperature for $30 \mathrm{~min}$. The absorbance was then measured at $517 \mathrm{~nm}$ in a UV-Vis Spectrophotometer. The lower absorbance of the reaction mixture indicates higher free radical scavenging activity. Ethanol was used as the solvent and ascorbic acid as the standard. The DPPH radical scavenging activity is designed by the following equation:

DPPH Scavenging effect $(\%)=\quad \begin{gathered}\mathrm{A}_{\mathrm{o}}-\mathrm{A}_{1} \\ -\mathrm{A}_{\mathrm{o}}\end{gathered}$

Where Ao is the absorbance of the control reaction and $A_{1}$ is the absorbance in the presence of the samples or standard.

\section{DNA binding studies}

The DNA binding experiments involving interaction of the $\mathrm{Cr}$ (III) complex and the ligands with calf thymus CT-DNA were conducted in Tris buffer containing $\mathrm{HCl}(0.01 \mathrm{M})$ adjusted to $\mathrm{pH} 7.2$ with hydrochloric acid. The CT-DNA was dissolved in Tris- $\mathrm{HCl}$ buffer and was dialyzed against the same buffer overnight. Solutions of CT-DNA gave the ratios of UV absorbance at 260 and $280 \mathrm{~nm}$ above 1.8, demonstrating that the
DNA was adequately free of protein. DNA concentration per nucleotide was determined by absorption spectroscopy using the molar absorption coefficient $6600 \mathrm{dm}^{3} \mathrm{~mol}^{-1} \mathrm{~cm}^{-1}$ at $260 \mathrm{~nm}$. The stock solutions were stored at $4^{\circ} \mathrm{C}$ and used within 4 days. ${ }^{17}$ For fluorescence-quenching experiments, DNA was pre-treated with ethidium bromide (EtBr) for $30 \mathrm{~min}$. The Cr(III) complex then added to this mixture and their effect on the emission intensity was measured. Samples were excited at $450 \mathrm{~nm}$ and emission was observed between $500 \mathrm{~nm}$ and $800 \mathrm{~nm}$.

\section{RESULTS}

\section{Selection of ligands}

Metal complexes with a variety of organic chelating ligand are also of current interest due to their biological activities. These include antiinflammatory and anticonvulsant properties, cytotoxicity and antiviral activity. The 2-aminobenzonitrile and octanoate ion are also organic ligands. These ligands can bind as neutral ligands or as anionic ligands in monodentate, bi dentate or bridging manner. The required mole ratio of 2-aminobenzonitrile in methanol and sodium octanoate in ethanol were added to the chromium chloride in methanol followed by microwave irradiation for few seconds after each addition by using microwave oven and the precipitate is filtered off, washed with 1:1 ethanol: water and characterized by elemental analysis, molar conductance, magnetic moment, electronic spectra, FT- IR, cyclic voltammetry, thermal analysis and powder-XRD techniques. The spectral data's indicates that the geometry of the complex is octahedral. The antimicrobial activities of ligands and their Cr(III) complex were studied by agar - well diffusion method. The free radical scavenging activity of the complex and the ligands has been determined by measuring their interaction with the stable free radical DPPH. DNA-binding properties have been studied by fluorescence-emission method.

\section{Characterization of free ligands and their Complex}

\section{Elemental analysis and molar conductance}

In Table 1, the elemental analysis results $(\mathrm{C}, \mathrm{H}, \mathrm{N})$ and the molar conductance value of the prepared complex.

\section{Electronic spectra and Magnetic moment}

In Figure 1, The electronic spectrum of $\mathrm{Cr}$ (III) complex exhibits three absorption bands at $540 \mathrm{~nm}, 390 \mathrm{~nm}$ and $280 \mathrm{~nm}$ for the electronic Spectrum of $\mathrm{Cr}$ (III) complexe. The magnetic moment at room température is $3.31 \mathrm{~B} . \mathrm{M}$.

\section{FT-IR Spectra}

In Figure 2a, 2b, the FT-IR spectra of 2- aminobenzonitrile shows in characteristic absorption bands in the $3453 \mathrm{~cm}^{-1}, 3366 \mathrm{~cm}^{-1}$ and 2206 $\mathrm{cm}^{-1}$ region, assignable to asymmetric, symmetric stretching frequencies of $v\left(\mathrm{NH}_{2}\right)$ and $v(\mathrm{C} \equiv \mathrm{N})$ respectively. ${ }^{18}$ A small band noticed at $3076 \mathrm{~cm}^{-1}$ is due to $v(\mathrm{CH})$ aryl. Aromatic $v(\mathrm{C}=\mathrm{C})$ stretching vibration is seen as a sharp peak at $1570 \mathrm{~cm}^{-1}$. The octanoate ion shows $v(\mathrm{C}-\mathrm{O})$ at $1207 \mathrm{~cm}^{-1}$ and the carbonyl group $v(\mathrm{C}=\mathrm{O})$ noticed at $1605 \mathrm{~cm}^{-1}$.

Table 1: Elemental analysis and molar conductance.

\begin{tabular}{ccccc}
\hline \multirow{2}{*}{ Complex } & \multicolumn{3}{c}{ \% of elements found } & \multicolumn{1}{c}{$\begin{array}{c}\mathrm{m}\left(\mathbf{\Omega}^{-1} \mathrm{~cm}^{2}\right. \\
\left.\mathbf{m o l}^{-1}\right)\end{array}$} \\
\cline { 2 - 4 } & Carbon & Hydrogen & Nitrogen & \\
\hline $\begin{array}{c}\text { Cr( III) } \\
\text { Complex }\end{array}$ & 68.91 & 8.13 & 6.15 & 65.92 \\
\hline
\end{tabular}




\section{Cyclic voltammetry of $\mathrm{Cr}(\mathrm{III})$ complex}

In Figure 3, the $\mathrm{Cr}$ (III) complex exhibits a reduction peak at Epc $=0.6 \mathrm{~V}$ with the corresponding oxidation peak at $\mathrm{Epa}=1.3 \mathrm{~V}$ and the scan rate of $50 \mathrm{mV} / \mathrm{s}$.

\section{Thermogravimetric analysis}

In Figure 4, Thermogravimetric analysis of $\mathrm{Cr}$ (III) complex of 2-aminobenzonitrile and octanoate ion shows two significant temperature transitions of weight loss with common and specific stages, termed as two stages of thermal degradation. The TGA plateau of the complex shows that the endothermic peak at $160^{\circ} \mathrm{C}$ and $280^{\circ} \mathrm{C}$.

\section{Powder X-ray diffraction technique}

In Figure 5, the Powder X-ray diffractogram of the Cr(III) complex was recorded in the range of $5^{\circ}$ to $80^{\circ} 2 \theta$ values. The XRD pattern indicates that the prepared complexes have well defined crystalline patterns, with various degrees of crystallinity. In the complex, the trend of the curves decreases from maximum to minimum intensity indicating amorphous nature of the complex.

\section{Biological activity}

\section{Antibacterial activity}

The free ligands and their $\mathrm{Cr}$ (III) complex were evaluated against the bacteria staphylococcus aureus, streptococcus, Escherichia coli, Klebsiella pneumonia, P. aeruginosa, salmonella typhi and Enterobacter at different concentration by using agar-well diffusion method. The results are given in the Table 2.

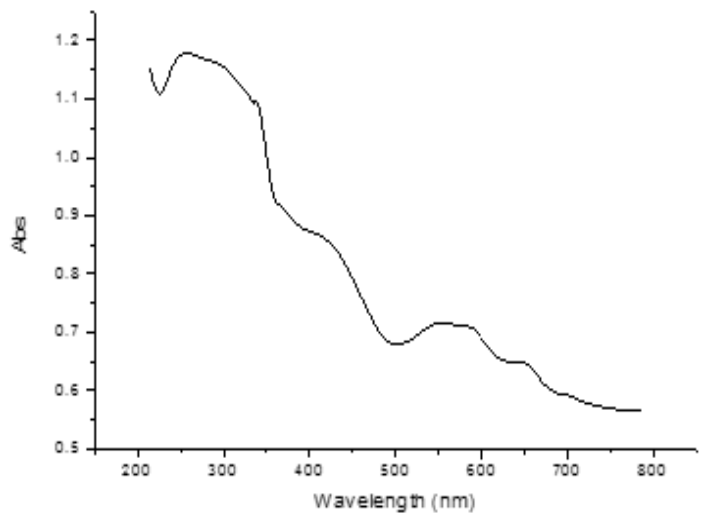

Figure 1: Electronic spectrum of $\mathrm{Cr}(\mathrm{III})$ complex.

\section{Antifungal activity}

The synthesized $\mathrm{Cr}$ (III) complex and the free ligands were evaluated against the fungi, viz., C.albicans, Aspergillus Niger and Aspergillus Flavus at different concentrations by agar-well diffusion method. The results are given in the Table 3.

\section{Antioxidantal activity (Radical Scavenging Activity)}

The 2,2"-diphenyl-1-picrylhydrazyl (DPPH) radical assay provides an easy and rapid way to evaluate the antiradical activities of antioxidants. Determination of the reaction kinetic types DPPHH is a product of the reaction between DPPH and an antioxidant.

The reversibility of the reaction is evaluated by adding DPPHH at the end of the reaction. If there is an increase in the percentage of remaining $\mathrm{DPPH}^{\cdot}$ at the plateau, the reaction is reversible, otherwise it is a complete reaction.

DPPH was used as stable free radical electron accepts or hydrogen radical to become a stable diamagnetic molecule. DPPH is a stable free radical containing an odd electron in its structure and usually used for detection of the radical scavenging activity in chemical analysis. The reduction capability of DPPH radicals was determined by decrease in its absorbance at $517 \mathrm{~nm}$ induced by antioxidants. The graph was plotted with percentage scavenging effects on the $y$-axis and concentration $(\mu \mathrm{g} /$ $\mathrm{mL}$.) on the $\mathrm{x}$-axis is given in Figure 7.

\section{DNA Binding - Emission study}

In Figure 8, the binding of $\mathrm{Cr}$ (III) complex to CT-DNA can be studied by competitive binding experiments. Ethidium bromide (EB) is known to show fluorescence when bound to DNA, due to its strong intercalation between the adjacent DNA base pair. The fluorescent light is quenched

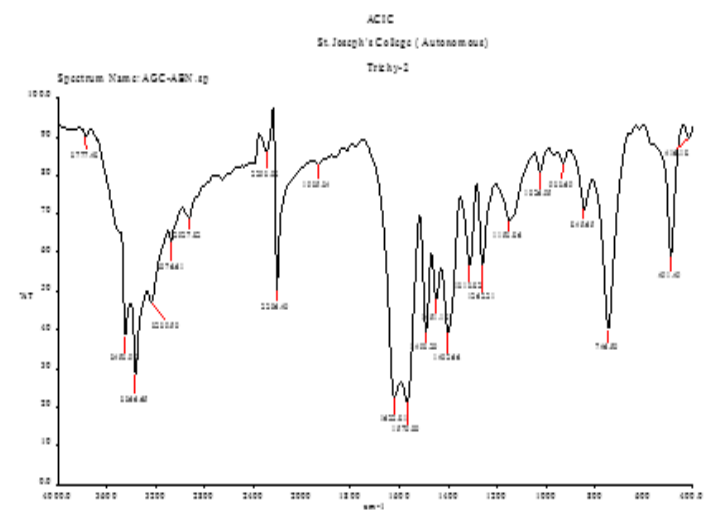

Figure 2a: FT IR Spectrum of 2-aminobenzonitrile.

Table 2: Antibacterial activity of the ligands and complex.

\begin{tabular}{|c|c|c|c|c|c|c|c|c|c|}
\hline \multirow[b]{2}{*}{ S. No } & \multirow{2}{*}{$\begin{array}{l}\text { Ligand/ } \\
\text { Complexes }\end{array}$} & \multirow{2}{*}{$\begin{array}{l}\text { Conc. } \\
\mu \mathrm{g} / \mathrm{ml}\end{array}$} & \multicolumn{7}{|c|}{ Zone of inhibition in diameter ( $\mathrm{mm})$} \\
\hline & & & S. aureus & Streptococcus & E. coli & Klebsiella & $\begin{array}{c}P . \\
\text { aeruginosa }\end{array}$ & $\begin{array}{c}\text { S. } \\
\text { typhi }\end{array}$ & $\begin{array}{l}\text { Entero } \\
\text { bacter }\end{array}$ \\
\hline \multirow{2}{*}{1} & \multirow{2}{*}{$2-\mathrm{ABN}$} & 50 & 04 & 05 & 06 & 11 & 14 & 10 & 11 \\
\hline & & 100 & 09 & 12 & 11 & 16 & 21 & 16 & 18 \\
\hline \multirow{2}{*}{2} & \multirow{2}{*}{$\mathrm{NaOC}$} & 50 & 04 & 05 & 05 & 04 & 11 & 03 & 05 \\
\hline & & 100 & 08 & 18 & 07 & 09 & 17 & 04 & 21 \\
\hline \multirow{2}{*}{3} & \multirow{2}{*}{ Cr(III) Complex } & 50 & 10 & 15 & 04 & 06 & 04 & 05 & 04 \\
\hline & & 100 & 21 & 29 & 10 & 09 & 11 & 08 & 08 \\
\hline
\end{tabular}

05-10 Resistant; 11-16 Moderate; 16-21 Highly activity; 21-30 Enhanced activity 
Table 3: Antifungal activity of the ligands and complex.

\begin{tabular}{|c|c|c|c|c|c|}
\hline \multirow{2}{*}{$\begin{array}{l}\text { S. } \\
\text { No }\end{array}$} & \multirow{2}{*}{$\begin{array}{l}\text { Ligands/ } \\
\text { Complexes }\end{array}$} & \multirow{2}{*}{$\begin{array}{l}\text { Conc. } \\
\mu \mathrm{g} / \mathrm{ml}\end{array}$} & \multicolumn{3}{|c|}{ Zone of Inhibition in diameter ( $\mathrm{mm}$ ) } \\
\hline & & & C. albicans & $\begin{array}{l}\text { Aspergillus } \\
\text { Niger }\end{array}$ & $\begin{array}{c}\text { Aspergillus } \\
\text { Flavus }\end{array}$ \\
\hline \multirow{2}{*}{1} & \multirow{2}{*}{$2-\mathrm{ABN}$} & 50 & 05 & 04 & 03 \\
\hline & & 100 & 07 & 05 & 05 \\
\hline \multirow{2}{*}{2} & \multirow{2}{*}{$\mathrm{NaOC}$} & 50 & 04 & 03 & 04 \\
\hline & & 100 & 05 & 05 & 05 \\
\hline \multirow{2}{*}{3} & $\mathrm{Cr}(\mathrm{III})$ & 50 & 05 & 04 & 03 \\
\hline & Complex & 100 & 07 & 05 & 15 \\
\hline
\end{tabular}

05-10 Resistant; 11-16 Moderate; 16-21 Highly activity; 21-30 Enhanced activity

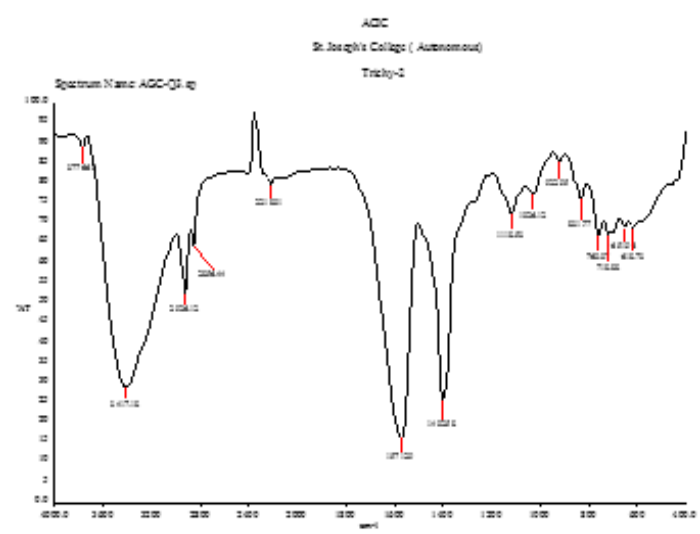

Figure 2b: FT IR Spectrum of Sodium octanoate.

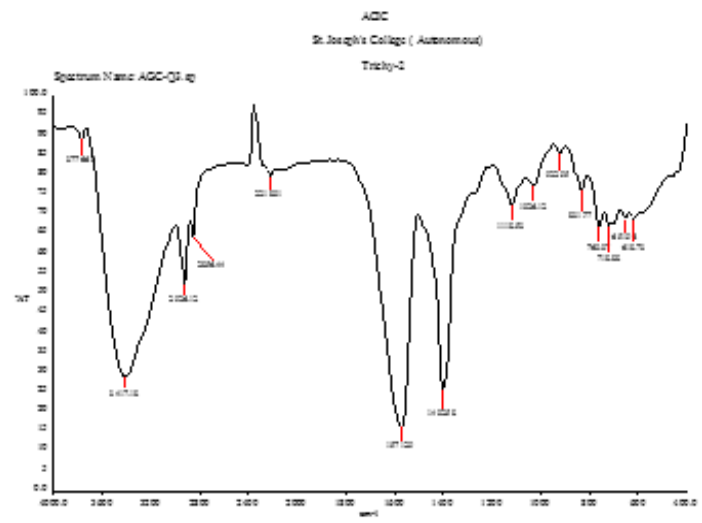

Figure 2c: FT IR Spectrum of Cr(III) complex

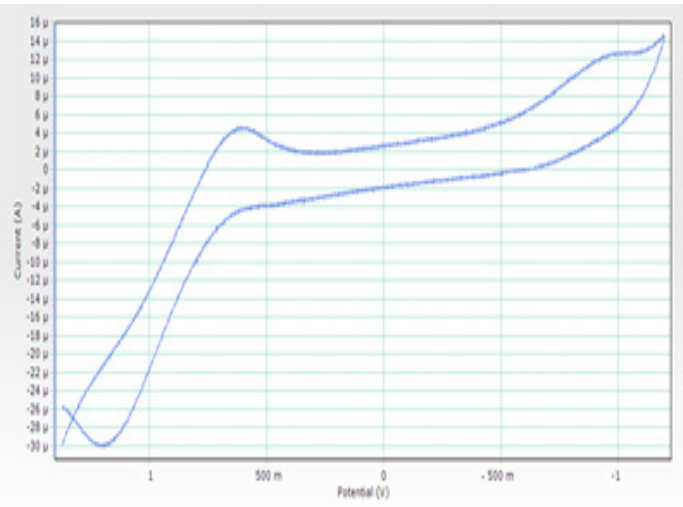

Figure 3: Cyclic voltammogram of $\mathrm{Cr}(\mathrm{III})$ complex.

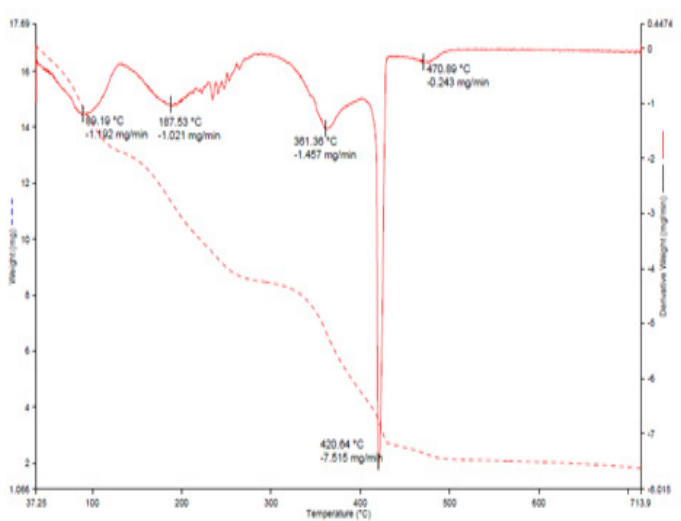

Figure 4: Thermogram of $\mathrm{Cr}(\mathrm{III})$ complex.

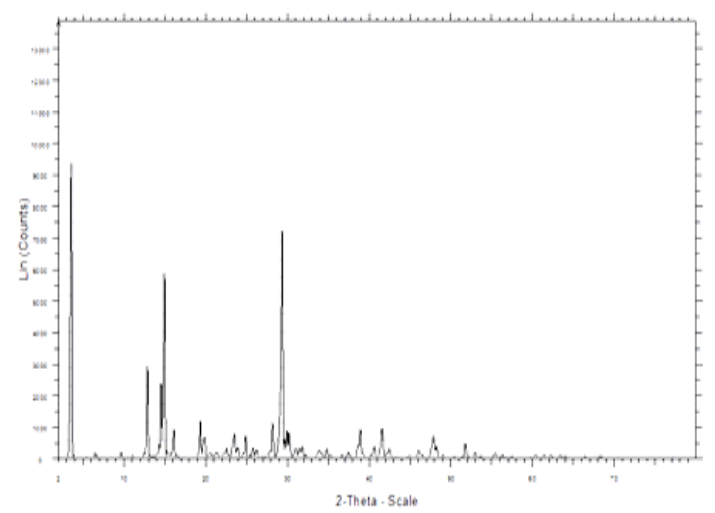

Figure 5: X-Ray Diffractogram of $\mathrm{Cr}$ (III) complex.

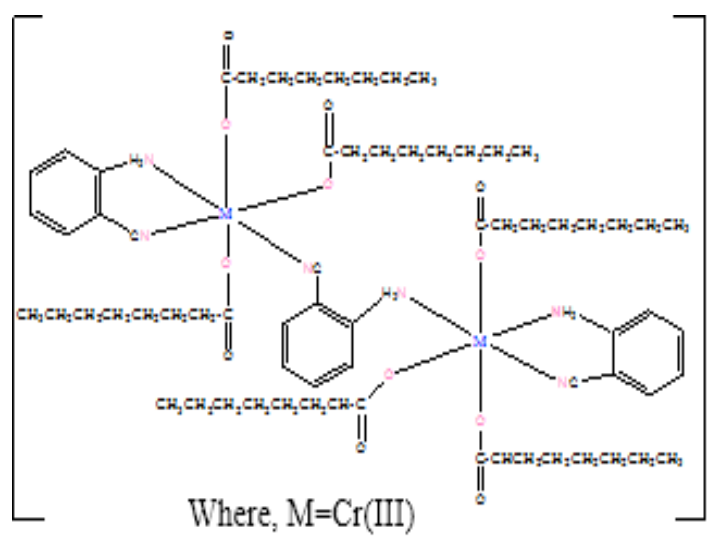

Figure 6: Octahedral dimeric structure of $\mathrm{Cr}(\mathrm{III})$ complex.

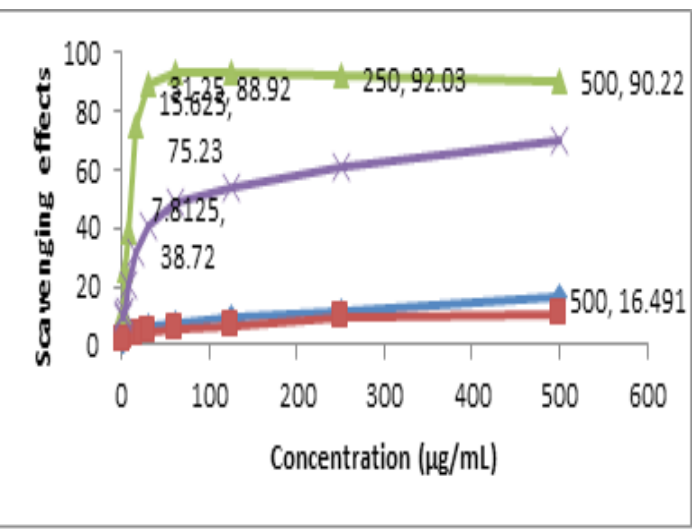

Figure 7: Antioxidant activity of $\mathrm{ABN}, \mathrm{NaOC}, \mathrm{Cr}(\mathrm{III})$ complex and Vitamin C. 


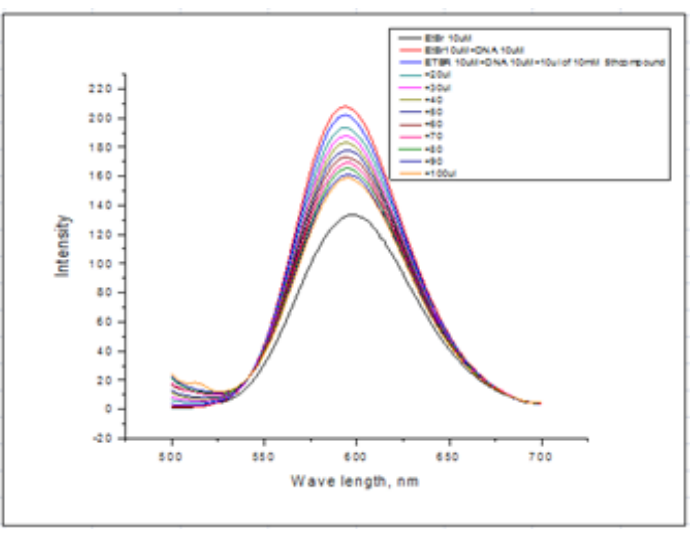

Figure 8: Emission spectrum of EtBr bound to DNA in the absence and presence of $\mathrm{Cr}(\mathrm{III})$ complex.

by the addition of a second molecule. The quenching extent of fluorescence of ethidium bromide binding to DNA is used to determine the extent of binding between the second molecule and DNA. The addition of the complex to DNA pretreated with ethidium bromide causes appreciable reduction in the emission intensity, indicating the replacement of the ethidium bromide fluorophore by the complex results in a decrease of the binding constant of the ethidium to the DNA.

\section{DISCUSSION}

The elemental analysis and metal estimation of the complex led to the formula $\left[\mathrm{Cr}_{2}(\mathrm{OC})_{6}(\mathrm{ABN})_{3}\right]$. The percentages of carbon, hydrogen and nitrogen in the complex were found to be 68.91 (69.01), 8.13(8.26) and 6.15(6.37) respectively. The experimental values are in good agreement with the theoretical values (given in the parentheses). The low electrical conductivity value indicates that the chromium complex is non-electrolytic nature (1:0) type, confirming its molecular formula $\left[\mathrm{Cr}_{2}(\mathrm{OC})_{6}(\mathrm{ABN})_{3}\right] .{ }^{19}$ The electronic spectrum of $\mathrm{Cr}(\mathrm{III})$ complex exhibits three absorption bands at $540 \mathrm{~nm}, 390 \mathrm{~nm}$ and $280 \mathrm{~nm}$, which are assignable to the transitions, ${ }^{4} \mathrm{~A}_{2 \mathrm{~g}} \rightarrow{ }^{4} \mathrm{~T}_{2 \mathrm{~g}}\left(v_{1}\right),{ }^{4} \mathrm{~A}_{2 \mathrm{~g}} \rightarrow{ }^{4} \mathrm{~T}_{2 \mathrm{~g}}(\mathrm{~F})\left(v_{2}\right)$ and ${ }^{4} \mathrm{~A}_{2 \mathrm{~g}} \rightarrow{ }^{4} \mathrm{~T}_{1 \mathrm{~g}}$ (P) $\left(v_{3}\right)$, respectively. The electronic spectrum of the chromium complex reported here is in reasonable agreement with those in literature..$^{20,21}$ The magnetic moment at room temperature is $3.31 \mathrm{~B} . \mathrm{M}$ which corresponds to the expected value for octahedral geometry and involving $\mathrm{d}^{2} \mathrm{sp}^{3}$ hybridisation in the $\mathrm{Cr}$ (III) metal ion. The observed magnetic moments are slightly less than the spin-only value probably due to the weak antiferromagnetic coupling of the spins of neighbouring $\mathrm{Cr}$ (III) through the $\mathrm{ABN}$ bridge in the possible dimeric complex and this lends support to the inference made from analytical data. ${ }^{22}$

In Figure 2c, FT IR spectra of 2-aminobenzonitrile and octanoate ion ligands were compared with $\mathrm{Cr}$ (III) complex. The band(s) are broadened at $3417 \mathrm{~cm}^{-1}$ and the nitrile group of the $\mathrm{ABN}$ underwent at $2228 \mathrm{~cm}^{-1}$ after complexation, indicating the coordination of amino nitrogen and nitrile group to the metal atom. In free octanoate ion the $v(\mathrm{C}-\mathrm{O})$ stretching at $1207 \mathrm{~cm}^{-1}$ get shifted to the frequencies of $1118 \mathrm{~cm}^{-1}$ in complex, which indicates the monodentate coordination of the octanoate ion through oxygen atom. Thus, the IR spectral data suggest that the $A B N$ is bound to the metal ion through the amino nitrogen and cyano nitrogen and OC is bound through the oxygen donor atom. ${ }^{23}$

The peak separation of cyclic voltammetry $(\Delta \mathrm{Ep})$ of the couple is $0.7 \mathrm{~V}$. With increasing scan rates, the $\Delta \mathrm{Ep}$ value also increases giving more evidence of quasi-reversible one electron transfer process $\mathrm{Cr}$ (III)/Cr(II) couple. ${ }^{24}$ The difference between forward and backward peak potentials can provide a rough evaluation of the degree of the reversibility. The ratio of cathodic to anodic peak height is less than one. However, the peak current increases with the increase of the square root of the scan rates.

The TGA plateau of the complexes shows that these complex exhibits no mass loss up to $100^{\circ} \mathrm{C}$, indicating the absence of coordinated water and a high thermal stability of the complexes. The weight loss at $160^{\circ} \mathrm{C}$ in TGA curves of complexes is termed the first stage of thermal degradation. In this case, the present weight loss is in the range of (46.57-49.82\%), which may be attributed to the decomposition of less stable 2-aminobenzonitrile. The onset of second step decomposition occurs at $280^{\circ} \mathrm{C}$, which gives the loss of octanoate ion (18.02 - $25.88 \%$ ) bonding with the metal complexes. The experimental values are in full agreement with the percent weight calculated on the basis of stoichiometry proposed for the complex. $^{25}$

The powder XRD patterns of the synthesized Cr(III) complex show sharp crystalline peaks indicating their crystalline phase. The average crystallite size $\left(\mathrm{d}_{\mathrm{XRD}}\right)$ of the complexes was calculated using Scherer's formula. The prepared complexes had an average crystallite size of $45 \mathrm{~nm}$ indicating its nanocrystalline in nature..$^{26,27}$

\section{Suggested structure of the Complex}

The proposed structure of complex based on the above mentioned physico-chemical and the spectral (elemental analysis, molar conductance, magnetic moment, electronic, FT-IR spectra, cyclic voltammetry, thermal analysis and powder XRD technique) studies, the tentative structures proposed for the complex is shown in Figure 6.

The antibacterial activity of the complex shows enhanced activity against Staphylococcus aureus, streptococcus and moderately active against the rest of the organisms. The increased activity of the metal complexes can be explained on the basis of chelation theory. ${ }^{28}$ It is known that chelation tends to make the ligand act as powerful and potent bactericidal agents, killing more number of bacteria than the ligand.

The antifungal activity of the complex shows enhanced activity against the tested fungi. A comparative study of zone of inhibition diameter values of the ligands and their complex indicate that the metal complex has a better fungicidal activity than the free ligands. This is probably due to the greater lipophilic nature of the complexes. It is evident from the data that this activity significantly increases on coordination. ${ }^{29}$

The metal complex showed enhance activity as a radical scavenger compared with ascorbic acid, these results were in good agreement with previous metal complexes studies where the ligand has the antioxidant activity and it is expected that the metal moiety will increase its activity. ${ }^{30,31}$ In the DNA binding study, the classical Stern-Volmer equation: Io/I = $1+$ Ksvr, where Io and I are the fluorescence intensities in the absence and the presence of complex respectively. Ksv is a linear Stern-Volmer quenching constant, $r$ is the ratio of the total concentration of complex to that of DNA. The quenching plots illustrate that the quenching of ethidium bromide bound to DNA by the complex are in good agreement with the linear Stern-Volmer equation, which also indicates that the complex binds to DNA. In the plot of $\mathrm{I}_{0} / \mathrm{I}$ versus $\mathrm{C}_{\mathrm{Complex}} / \mathrm{C}_{\mathrm{DNA}}, \mathrm{K}$ is given by the ratio of the slope to intercept. The $\mathrm{K}$ values for $\mathrm{Cr}$ (III) is 5.47. The data suggest that the interaction of $\mathrm{Cr}$ (III) complex with DNA is strongest, which is consistent with the above absorption spectral results. $\mathrm{K}$ values indicate that the interaction of the complex with DNA is a intercalative mode. ${ }^{32}$

\section{CONCLUSION}

In the present study, our efforts were to synthesize and characterize the $\mathrm{Cr}$ (III) metal complex with 2-aminobenzonitrile and octanoate ion as ligands. The new complex was synthesized using microwave irradiation. The synthesized metal complex were characterized by various physicochemical and spectral analyses. Based on the analytical, molar conduc- 
tance, spectral and magnetic moment, octahedral geometry has been suggested for the $\mathrm{Cr}$ (III) complex. The synthesized complex was tested for antimicrobial activities. The metal complex has significant antimicrobial and antioxidantal activities as compared to the free ligands. The effectiveness of the DNA binding of the complexes is being confirmed by means of change in intensity of emission in the case of emission spectral studies.

\section{ACKNOWLEDGEMENT}

The authors thank the Management and the Principal of Thanthai Hans Roever College (Autonomous), Perambalur, Tamil Nadu, India for permitting them to carry out this work. The authors are also thankful the Heads, SAIF, IIT Madras, IIT-Roorkee, IIT-Bombay and the Director, STIC, Cochin for providing the spectral data.

\section{CONFLICT OF INTEREST}

The authors declare that there is no conflict of Interest.

\section{ABBREVIATIONS}

ABN: 2- aminobenzonitrile; NaOC: Sodium benzoate.

\section{REFERENCES}

1. Perry IJJ, Perman JA, Zaworotko MJ. Design and synthesis of metal-organic frameworks using metal-organic polyhedra as supermolecular building blocks. Chem Soc Rev. 2009;38(5):1400-17.

2. Batten SR, Robson R. Interpenetrating nets: ordered, periodic entanglement. Angewandte Chemie International Edition. 1998;37(11):1460-94.

3. Chen B, Xiang S, Qian G. Metal-organic frameworks with functional pores for recognition of small molecules. Acc Chem Res. 2010;43(8):1115-24.

4. Robson RJ. A net-based approach to coordination polymers. J Chem Soc Dalton Trans. 2000;2000(21):3735-44.

5. Zhang JP, Kitagawa S. Supramolecular isomerism, framework flexibility, unsaturated metal center and porous property of ag (i)/cu (i) 3, 3', 5, 5 '-tetrametyl-4 4 '-bipyrazolate. J Am Chem Soc. 2008;130(3):907-17.

6. Kasuga NC, Sugie A, Nomiya K. Syntheses, structures and antimicrobial activities of water-soluble silver (I)-oxygen bonding complexes with chiral and racemic camphanic acid (Hca) ligands. Dalton Trans. 2004;(21):3732-40.

7. Sun D, Yang CF, Xu HR, Zhao HX, Wei ZH, Zhang N, et al. Synthesis, characterization and property of a mixed-valent Agl/Agll coordination polymer. Chem Commun. 2010;46(43):8168-70.

8. Sun D, Wang DF, Han XG, Zhang N, Huang RB, Zheng LS. Stepwise assembly of two 3d-4d heterometallic coordination polymers based on a hexanuclear silver (I) metalloligand. Chem Commun. 2011;47(2):746-8.

9. Moulton B, Lu J, Hajndl R, Hariharan S, Zaworotko MJ. Crystal engineering of a nanoscale Kagomé lattice. Angewandte Chemie International Edition. 2002;41(15):2821-4.

10. Tang JH, Shi DX, Zhang LJ, Zhang Q, Li JR. Facile and One-Pot Synthesis of 1, 2-Dihydroquinazolin-4 (3 H)-ones via Tandem Intramolecular Pinner/Dimroth Rearrangement. Synth Commun. 2010;40(5):632-41.

11. Kabri Y, Gellis A, Vanelle P. Microwave-assisted synthesis in aqueous medium of new quinazoline derivatives as anticancer agent precursors. Green Chem. 2009;11(2):201-8

12. Patil YP, Tambade PJ, Parghi KD, Jayaram RV, Bhanage BM. Synthesis of quinaz- oline-2, $4(1 \mathrm{H}, 3 \mathrm{H})$-diones from carbon dioxide and 2-aminobenzonitriles using $\mathrm{MgO} / \mathrm{ZrO} 2$ as a solid base catalyst. Catalysis Let. 2009;133(1-2):201-8.

13. Abram U, Ortner K, Gust R, Sommer K. Gold complexes with thiosemicarbazones: Reactions of bi-and tridentate thiosemicarbazones with dichloro [2-(dimethylaminomethyl) phenyl-C 1, N] gold (III), [Au (damp-C 1, N) Cl 2]. Journal of the Chemical Society, Dalton Trans. 2000(5):735-44.

14. Galema SA. Microwave chemistry. Chem Soc Rev. 1997:26(3):233-8.

15. Govindharaju R, Balasubramaniyan S, Palanivelan L, Rajasekar K, Ramachandramoorthy T. Preparation, spectral characterization, thermal stability and biological activities of $\mathrm{Mn}(\mathrm{II})$ complex with 2-aminobenzonitrile and octanoate. World J Pharm Res. 2014;3(8):788-95

16. Chen $Y$, Wang M, Rosen RT, Ho CT. 2, 2-Diphenyl-1-picrylhydrazyl radical-scavenging active components from Polygonum multiflorum Thunb. J Agric Food Chem. 1999;47(6):2226-8.

17. Govindharaju R, Durairaj P, Maruthavanan T, Marlin RM, Ramachandramoorthy T Synthesis, Spectral Characterization and Pharmacological Significance of $\mathrm{Cr}(\mathrm{III})$ and $\mathrm{Mn}(\mathrm{II})$ Complexes with Schiff Base and Thiocyanate Ion as Ligands. Int J Pharm Sci Drug Res. 2019;11(5):174-80.

18. Akocak S, Boga M, Lolak N, Tuneg M, Sanku RK. Design, synthesis and biological evaluation of 1, 3-diaryltriazene-substituted sulfonamides as antioxidant acetylcholinesterase and butyrylcholinesterase inhibitors. Turk J Chem Soc Section A: Chem. 2019;6(1):63-70

19. Govindharaju R, Balasubramaniyan S, Rajasekar K, Palanivelan L, Ramachandramoorthy T. Synthesis, Spectral Characterization and Biological activities of $\mathrm{Cd}(\mathrm{II})$ complex with 2-aminobenzonitrile and octanoate ion as Ligands. J App Chem. 2016:9(5):37-41.

20. DosSantos JE, Dockal ER, Cavalheiro ÉT. Thermal behavior of Schiff bases from chitosan. J Therm Anal Calorim. 2005;79(2):243-8.

21. Islam MR, Shampa JA, Kudrat-E-Zahan M, Haque MM, Reza Y. Investigation on spectroscopic, thermal and antimicrobial activity of newly synthesized binuclear $\mathrm{Cr}(\mathrm{III})$ metal ion complex. J Sci Res. 2016;8(2):181-9.

22. Cotton FA, Wilkinson G, Murillo CA, Bochmann M, Grimes R. Advanced inorganic chemistry. New York: Wiley; 1988;6.

23. Govindharaju R, Balasubramaniyan S, Palanivelan L, Risana MM and Meenakshi VM: Synthesis, characterization and binding properties towards CT-DNA of mixed-ligand $\mathrm{Cu}(\mathrm{II})$ complex with 2-aminobenzonitrle and octanoate ion. Int J Pharm Sci \& Res 2019; 10(11):5137-45

24. Yee EL, Cave RJ, Guyer KL, Tyma PD, Weaver MJ. A survey of ligand effects upon the reaction entropies of some transition metal redox couples. J Am Chem Soc. 1979;101(5):1131-7.

25. Dash DC, Panda AK, Jena P, Patjoshi SB, Mohapatra A. Synthesis of some transition metal complexes with 4-(phenyl. J Indian Chem Soc. 2002;79(1):48-50.

26. Turkoglu O, Soylak M, Belenli I. Electrical conductivity of chloro (phenyl) glyoxime and its $\mathrm{Co}$ (II), Ni(II) and Cu(II) complexes. Collect Czech Chem. 2003;68(7):1233-42

27. Justin DC, Sivasankaran NM. Synthesis, characterization and antimicrobial studies of some Schiff-base metal (II) complexes. J Calorim Chem. 2009;62(24):4018-28

28. Sengupta SK, Pandey OP, Srivastava BK, Sharma VK. Synthesis, structural and biochemical aspects of titanocene and zirconocene chelates of acetylferroceny thiosemicarbazones. Transit Metal Chem. 1998;23(4):349-53.

29. Ahmad R, Ali AM, Israf DA, Ismail NH, Shaari K, Lajis NH. Antioxidant, radicalscavenging, anti-inflammatory, cytotoxic and antibacterial activities of methanolic extracts of some Hedyotis species. Life Sci. 2005;76(17):1953-64

30. Soare JR, Dinis TC, Cunha AP, Almeida L. Antioxidant activities of some extracts of Thymus zygis. Free Radi Res. 1997;26(5):469-78.

31. Duh PD, TuYY, Yen GC. Antioxidant activity of water extract of Harng Jyur (Chrysanthemum morifolium Ramat). LWT-Food Sci Technol. 1999;32(5):269-77.

32. Lakowicz JR, Weber G. Quenching of fluorescence by oxygen. Probe for structural fluctuations in macromolecules. Biochemistry. 1973;12(21):4161-70.

Cite this article: Govindharaju R, Muruganantham N, Balasubramaniyan S, Palanivelan L, Jayalakshmi B, Rajalakshmi K, Ramachandramoorthy T. Synthesis, Spectral Characterization and Biological Evaluation of Cr(III) Complex with Mixed N,N and O-donor Ligands. Int. J. Pharm. Investigation. 2019;9(4):158-63. 